\title{
Serum Metabolic Profile during Early Lactation in Amrit Mahal, Holstein Friesian Crossbred and Jersey Crossbred Cows
}

\author{
V. Praveen, M. Narayana Swamy, G.P. Kalmath, H.S. Shwetha*, \\ M.K. Vinuthan, M. Narasimhamurthy and M.P. Veena
}

Department of Veterinary Physiology, Veterinary College, Bengaluru- 560024, India

*Corresponding author

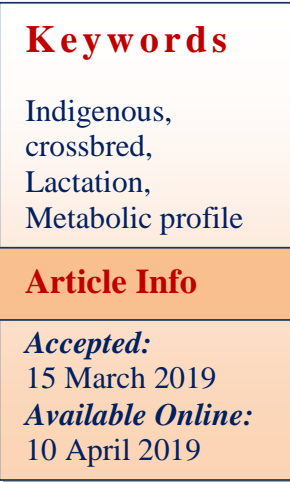

A B S T R A C T

\section{Introduction}

The term lactation refers to the combined process of milk secretion from the alveolar cells and milk removal from the alveolar lumen (Park and Lindberg, 2005). The increased metabolic activity of dairy cows is seen during parturition and at the onset of lactation. During early lactation, the levels of serum metabolites and lipid components are altered. The glucose metabolites such as acetate and $\beta$-hydroxybutyrate are the most important energy metabolites in the mammary gland of ruminants. The blood glucose precursors and cofactors generated during the glucose metabolism are involved in the synthesis of milk protein, fat and lipid. Blood albumin and globulin directly enters the mammary cells as preformed proteins and secreted in milk through intracellular 
transport mechanism (Park and Lindberg, 2005).

The metabolic alterations in dairy animals were common during two major stages of life i.e., during pregnancy and lactation (Krajnicako et al., 2003). The most important tool to assess the nutritional and physiological status of the dairy animals in modern dairy husbandry is the determination of the metabolic profile. The metabolites in the blood are used to indicate the level of nutrient metabolism (Ndlovu et al., 2007). There is paucity of information on the comparative studies of blood metabolic profile between indigenous (Amrit Mahal) and crossbred dairy cows. Hence, the present study was undertaken to determine and compare the various components of blood metabolic profile in Amrit Mahal, Holstein Friesian crossbred and Jersey crossbred cows.

\section{Materials and Methods}

The present research was approved by the Institutional Animal Ethics Committee (VCH/IAEC/2018/57) dated 13.03.2018. The study was carried out on six each of Amrit Mahal cattle breed from Chitradurga district, Holstein Friesian crossbred and Jersey crossbred cows from Bangalore Rural and Chikkaballapur districts of Karnataka. These animals were selected from different dairy farms and individual farmers on the basis of iso-nutritional and iso-managemental conditions.

The animals were randomly selected and they were screened for sub-clinical mastitis by California Mastitis test to exclude mastitis affected cows, if any (Badiuzzaman et al., 2015). Only the negative animals in CMT were considered for the present study. A total of 18 cows with six cows belonging to each breed in their third lactation were selected and divided into three groups viz. Amrit Mahal cows (Group I), Holstein Friesian crossbred (Group II) and Jersey crossbred cows (Group III).

Blood samples were collected aseptically from jugular vein at $4^{\text {th }}, 8^{\text {th }}$ and $12^{\text {th }}$ week of the lactation between the months of March 2018 to June 2018. About $5 \mathrm{ml}$ of blood was collected each time and was allowed to clot for about an hour in the clot activated vacutainer. The serum obtained by centrifuging the coagulated blood samples (5000 rpm for $5 \mathrm{~min}$ ) were stored at $-20{ }^{\circ} \mathrm{C}$ till they were subjected for analysis. The serum metabolic profile was determined in the Department of Veterinary Physiology, Veterinary College, Hebbal, Bengaluru, using microlab 300 semi-automated biochemical analyzer (Lab-care Diagnostics Pvt. Ltd., Gujarat) with the help of commercial reagent kits. The data obtained were analyzed by two way ANOVA using GraphPad Prism version 7.04 (2018) computerized software.

\section{Results and Discussion}

The serum glucose level was significantly lower during fourth week compared to $12^{\text {th }}$ week of lactation in all three groups (Table 1). These findings were in agreement with the reports of Hagawane et al., (2009) in Lactating Murrah, Jaffarabadi, Nagpuri and non-d descript buffaloes and Das et al., (2016) in Mehshani buffaloes. Hagawane et al., (2009) attributed the lower serum glucose level during early lactation to higher milk production after parturition which demands high energy. Das et al., (2016) attributed the lower blood glucose to enhanced utilization of glucose for milk lactose synthesis by mammary gland during early lactation in buffaloes. In the present study, it was concluded that the significantly lower levels of serum glucose during $4^{\text {th }}$ week compared to $12^{\text {th }}$ week of lactation could be due to increased mobilization of glucose from the 
bloodstream to mammary gland and enhanced glucose uptake by mammary cells to cope up with higher milk synthesis or it might also be due to reduced feed intake as a result of oxidative stress in the animals during very early part of lactation.

The serum total protein level was significantly lower during fourth week compared to $12^{\text {th }}$ week in Group I (Table 1). These findings were in agreement with the results of Yaylak et al., (2009), where they attributed the lower total protein level in early stage of lactation to the higher maternal proteins requirements for synthesis of milk components. Thus, it is concluded that the lower serum total protein level during $4^{\text {th }}$ week compared to $12^{\text {th }}$ week could be due to the increased mobilization of amino acids, especially lysine and methionine, from the blood stream to the mammary gland for milk protein synthesis to cope up with the higher milk production.

Serum albumin levels were significantly higher during fourth week compared to $12^{\text {th }}$ week of lactation in Holstein Friesian crossbred cows (Table 1). Similar were the findings of Rana et al., (2008) in dairy cows who have attributed the higher albumin level to enhanced transportation of several nutrients such as calcium, phosphorus, free fatty acids, fat soluble vitamins etc. to the mammary gland. However, Celeska et al., (2015) in Holstein cows reported that there was gradual increase in the level of serum albumin in the later stage of lactation. It is concluded that the higher albumin level might be due to involvement of udder defence mechanism during early part of lactation or could be meet the amino acid requirement to new born calf through secretion of high amount of $\alpha$ lactalbumin (major whey protein) in the milk.

The significant increase in serum globulin levels were recorded on $12^{\text {th }}$ week of lactation compared to $4^{\text {th }}$ week in Amrit Mahal, Holstein Friesian crossbred and Jersey crossbred cows (Table 1). The results were in agreement with the findings of Janku et al., (2011) in white short haired goats and Coroian et al., (2017) in Holstein cows. It is concluded from the study that the lower level of globulin during fourth week compared to $12^{\text {th }}$ week of lactation recorded in the present study could be attributed to higher requirement of protein and immunoglobulin by the mammary gland for milk component synthesis.

In the present study, significantly higher $\mathrm{A} / \mathrm{G}$ ratio was observed on $4^{\text {th }}$ week of lactation compared to $12^{\text {th }}$ week in Amrit Mahal, Holstein Friesian crossbred and Jersey crossbred cows (Table 1). These findings were in corroboration with the reports of Russell and Roussel (2007) in ruminants and Tothova et al., (2018) in dairy cows. However, Kaneko et al., (1997) reported fairly constant levels of $\mathrm{A} / \mathrm{G}$ ratio in healthy cattle. Therefore, it was concluded that the significantly higher $\mathrm{A} / \mathrm{G}$ ratio during early weeks compared to $12^{\text {th }}$ week of lactation could be due to alteration in the level of serum globulin.

The serum urea nitrogen level was significantly lower in Amrit Mahal cows compared to Holstein Friesian crossbred cows during different weeks of lactation however, it was significantly different in Amrit Mahal cows compared Jersey crossbred cows only during $12^{\text {th }}$ week of lactation (Table 1). The findings were in consistent with the results of Nozad et al., (2012) in Holstein cows, where they attributed the high serum urea nitrogen levels in crossbred cows to their high milk producing ability compared to low producing indigenous cows. From the present study, it is concluded that the lower level of serum urea nitrogen during early part of lactation could be due to increased utilisation of amino acids 
by indigenous cows compared to crossbred cows. In Holstein Friesian crossbred cows and Jersey crossbred cows, the serum urea nitrogen level was significantly increasing from fourth week to twelfth week of lactation. These findings were in accordance with the reports of Cavestany et al., (2005) in dairy cows, and Elitok et al., (2006) in Holstein cows. Moreover, Elitok et al., (2006) owed the lower serum urea nitrogen level to the consequence of reduced anabolism of protein due to fatty infiltration during early lactation. Cavestany et al., (2005) attributed the gradual increase in serum urea nitrogen level to increased deamination or increased protein intake after calving. However, Das et al., (2016) in Mehshani buffaloes observed higher blood urea nitrogen in the initial stage of lactation and it decreased as the lactation progressed.

Table.1 Mean \pm SE values of certain metabolic profile in different groups of lactating cows $(\mathrm{n}=6)$

\begin{tabular}{|c|c|c|c|c|}
\hline \multirow[t]{2}{*}{ Parameters } & \multirow[t]{2}{*}{ Groups } & \multicolumn{3}{|c|}{ Weeks of Lactation } \\
\hline & & $4^{\text {th }}$ week & $8^{\text {th }}$ week & $12^{\text {th }}$ week \\
\hline \multirow{3}{*}{$\begin{array}{l}\text { Serum } \\
\text { glucose } \\
(\mathbf{m g} / \mathbf{d L})\end{array}$} & Group I & $44.55 \pm 2.59^{\mathrm{Aa}}$ & $51.78 \pm 2.29^{\mathrm{ABa}}$ & $56.45 \pm 2.28^{\mathrm{Ba}}$ \\
\hline & Group II & $49.11 \pm 1.21^{\mathrm{Aa}}$ & $56.74 \pm 1.51^{\mathrm{ABa}}$ & $59.68 \pm 0.79^{\mathrm{Ba}}$ \\
\hline & Group III & $44.81 \pm 4.04^{\mathrm{Aa}}$ & $50.49 \pm 3.92^{\mathrm{ABa}}$ & $55.76 \pm 2.79^{\mathrm{Ba}}$ \\
\hline \multirow{3}{*}{$\begin{array}{l}\text { Serum total } \\
\text { protein } \\
\text { (g/dL) }\end{array}$} & Group I & $7.58 \pm 0.15^{\mathrm{Aa}}$ & $7.92 \pm 0.13^{\mathrm{ABa}}$ & $8.40 \pm 0.16^{\mathrm{Ba}}$ \\
\hline & Group II & $7.85 \pm 0.34^{\mathrm{Aa}}$ & $8.27 \pm 0.35^{\mathrm{Aa}}$ & $8.45 \pm 0.18^{\mathrm{Aa}}$ \\
\hline & Group III & $7.65 \pm 0.26^{\mathrm{Aa}}$ & $8.11 \pm 0.19^{\mathrm{Aa}}$ & $8.35 \pm 0.15^{\mathrm{Aa}}$ \\
\hline \multirow{3}{*}{$\begin{array}{l}\text { Serum } \\
\text { albumin } \\
(\mathrm{g} / \mathbf{d L})\end{array}$} & Group I & $3.34 \pm 0.10^{\mathrm{Aa}}$ & $3.10 \pm 0.10^{\mathrm{Aa}}$ & $2.98 \pm 0.10^{\mathrm{Aa}}$ \\
\hline & Group II & $3.49 \pm 0.13^{\mathrm{Ba}}$ & $3.20 \pm 0.09^{\mathrm{ABa}}$ & $3.08 \pm 0.06^{\mathrm{Aa}}$ \\
\hline & Group III & $3.41 \pm 0.01^{\mathrm{Aa}}$ & $3.19 \pm 0.11^{\mathrm{Aa}}$ & $3.17 \pm 0.13^{\mathrm{Aa}}$ \\
\hline \multirow{3}{*}{$\begin{array}{l}\text { Serum } \\
\text { globulin } \\
\text { (g/dL) }\end{array}$} & Group I & $4.24 \pm 0.18^{\mathrm{Aa}}$ & $4.79 \pm 0.20^{\mathrm{ABa}}$ & $5.41 \pm 0.11^{\mathrm{B}}$ \\
\hline & Group II & $4.35 \pm 0.25^{\mathrm{Aa}}$ & $5.07 \pm 0.34^{\mathrm{ABa}}$ & $5.34 \pm 0.16^{\mathrm{Ba}}$ \\
\hline & Group III & $4.18 \pm 0.27^{\mathrm{Aa}}$ & $4.92 \pm 0.18^{\mathrm{Ba}}$ & $5.17 \pm 0.06^{\mathrm{Ba}}$ \\
\hline \multirow{3}{*}{$\begin{array}{l}\text { Albumin } \\
\text { globulin } \\
\text { ratio }\end{array}$} & Group I & $0.79 \pm 0.05^{\mathrm{Ba}}$ & $0.66 \pm 0.05^{\mathrm{ABa}}$ & $0.55 \pm 0.02^{\mathrm{Aa}}$ \\
\hline & Group II & $0.81 \pm 0.04^{\mathrm{Ba}}$ & $0.64 \pm 0.04^{\mathrm{Aa}}$ & $0.57 \pm 0.02^{\mathrm{Aa}}$ \\
\hline & Group III & $0.82 \pm 0.06^{\mathrm{Ba}}$ & $0.65 \pm 0.04^{\mathrm{Aa}}$ & $0.61 \pm 0.03^{\mathrm{Aa}}$ \\
\hline \multirow{3}{*}{$\begin{array}{l}\text { Serum urea } \\
\text { nitrogen } \\
\text { (mg/dL) }\end{array}$} & Group I & $8.87 \pm 1.76^{\mathrm{Aa}}$ & $11.61 \pm 1.67^{\mathrm{Aa}}$ & $12.59 \pm 1.90^{\mathrm{Aa}}$ \\
\hline & Group II & $19.60 \pm 1.84^{\mathrm{Ab}}$ & $28.04 \pm 4.15^{\mathrm{Bb}}$ & $28.16 \pm 1.65^{\mathrm{Bc}}$ \\
\hline & Group III & $11.87 \pm 1.24^{\mathrm{Aa}}$ & $17.64 \pm 1.48^{\mathrm{ABa}}$ & $20.54 \pm 1.42^{\mathrm{Bb}}$ \\
\hline
\end{tabular}

The values with different superscripts within a row (A and B) and within a column ( $\mathrm{a}, \mathrm{b}$ and $\mathrm{c}$ ) differ significantly $(\mathrm{P}<0.05)$

The lower serum urea nitrogen in early part of lactation observed in all the breeds of cattle could be related to higher milk production and increased drainage of urea from the blood into the milk during peak milk production (i.e. early lactation) or it might also be due to lowered protein synthesizing ability of the liver during fatty infiltration. The lowered serum urea nitrogen observed in the study might also be the result of reduced dietary protein intake due to lactation tress during early part of the lactation.

In conclusion, the results of the present study indicated that the lactation significantly affects the serum metabolic status of lactating 
animals during early lactation. Therefore, there is a huge demand of metabolites during peak milk production at early lactation in dairy animals. This leads to more metabolic changes in lactating animals altering the level of serum metabolic profile. Metabolic disorders in dairy cows during early lactation have negative impact on their health and production potential. Therefore, monitoring the metabolic status of the lactating animal will be of great importance for optimum milk production especially in high yielding dairy cows like HF and Jersey crossbred cows.

\section{References}

Badiuzzaman, M., Samad, M. A., Siddiki, S. H. M. F., Islam, M. T. and saha, S., 2015. Subclinical mastitis in lactating cows: Comparison of four screening tests and effect of animal factors on its occurrence. Bangl. J. Vet. Med., 13(2):41-50

Cavestany, D., Blanc, J. E., Kulcsar, M., Uriarte, G., Chilibroste, P., Meikle, A., Febel, H., Ferraris, A. and Krall, E., 2005. Studies of the transition cow under a pasture based milk production system: metabolic profiles. J. Vet. Med. Sci., 52(1): 1-7

Celeska, I., Janevski, A., Dzadzovski, I., Ulchar, I. and Kirovski, D., 2015. The dynamics of biochemical parameters in blood of clinically healthy Holstein cows from day 5 before to day 60 after calving. Mac. Vet. Rev., 38(2): 189193

Coroian, C. O., Miresan, V., Coroian, A., Raducu, C., Andronie, L., Marchis, Z., Terhes, S. and Muntean, M., 2017.Biochemical and haematological blood parameters at different stages of lactation in cows. Bulletin UASVM Anim. Sci. Biotech., 74(1): 31-36

Das, H., Lateef, A., Panchasara, H. H., and Ali, M. A., 2016. Haemato- biochemical alterations during different stages of lactation in Mehshani buffaloes. Buffalo Bulletin., 35(3): 307-315

Elitok, B., Kabu, M. and Elitok, O. M., 2006. Evaluation of liver function tests in cows during periparturient period. $F a$ rat Universitesi Saalak Bilimler iDergisi (Veteriner) 20: 205-209

Janku, L., Pavlata, L., Misurova, L., Filipek, J., Pechova, A. and Dvorak, R., 2011. Levels of protein fractions in blood serum of peri-parturient goats.Acta Vet. Brno., 80: 185-190

Hagawane, S. D., Shinde, S. B. and Rajguru, D. N., 2009. Haematological and blood biochemical profile in lactating buffaloes in and around Parbhani city. Vet. World, 2: 467-469

Kalmath, G. P., Narayana Swamy, M. and Yathiraj, S., 2013. Effect of summer stress and supplementation of vitamin $\mathrm{E}$ and selenium on serum lipid profile in Hallikar cattle. Int. J. Sci. Res., 4: 95-97

Kaneko, J. J., 1997. Serum proteins and the dysproteinemias. In: Clinical biochemistry of domestic animals. Edt. Kaneko, J. J., Harvey, J. W. and Bruss, M. L. Edn. $5^{\text {th }}$. San Diego (CA): Academic Press; pp: 117-138

Karapehlivan, M., Atakisi, E., Atakisi, O., Yucayurtand, R. and Pancarci, S. M., 2007. Blood biochemical parameters during the lactation and dry period in Tujewes. Small Ruminant Res., 73(1): 267-271

Nozad, S., Ramin, A. G., Moghadam, G., Asri-Rezaei, S., Babapour, A. and Ramin, S., 2012. Relationship between blood urea, protein, creatinine, triglycerides and macromineral concentrations with the quality and quantity of milk in dairy Holstein cows. Vet. Res. 3(1): 55-59

Park, C. S. and Lindberg, G. L., 2015.The 
Mammary Gland and Lactation. In: Dukes Physiology of Domestic Animals. Edt. Reece, W. O., Edn. $12^{\text {th }}$, Panima Publishing Corporation. New Delhi., $p p$ : 720-741

Rana, T., Sarkar, S., Mandal, T. and BATABYAL, S., 2008.Haematobiochemical profiles of affected cattle at arsenic prone zone in Haringhata block of Nadia district of west Bengal in India. The Internet J. Hematology., 4(2): 9-15

Russell, K. E. and Roussel, A. J., 2007. Evaluation of the ruminant serum chemistry profile. Vet. Clin. Food Anim., 23(3): 403-426

Tothova, C. S., Nagy, O., Nagyova, V. and KOVAC, G., 2018.Serum protein electrophoretic pattern in dairy cows during the periparturient period. $J$. Appl. Anim. Res., 46(1): 33-38

Yaylak, E., Yenisey, C. and Seyrek, K., 2009. Effects of lameness, stage of lactation and body condition score on some blood parameters in Holstein Cows. Asian J. Anim. Vet. Adv., 4: 245-251

\section{How to cite this article:}

Praveen, V., M. Narayana Swamy, G.P. Kalmath, H.S. Shwetha, M.K. Vinuthan, M. Narasimhamurthy and Veena, M.P. 2019. Serum Metabolic Profile during Early Lactation in Amrit Mahal, Holstein Friesian Crossbred and Jersey Crossbred Cows. Int.J.Curr.Microbiol.App.Sci. 8(04): 1996-2001. doi: https://doi.org/10.20546/ijcmas.2019.804.233 